\title{
Drifting snow measurements on the Greenland Ice Sheet and their application for model evaluation
}

\author{
J. T. M. Lenaerts ${ }^{1}$, C. J. P. P. Smeets ${ }^{1}$, K. Nishimura ${ }^{2}$, M. Eijkelboom ${ }^{1}$, W. Boot ${ }^{1}$, M. R. van den Broeke ${ }^{1}$, and \\ W. J. van de Berg ${ }^{1}$ \\ ${ }^{1}$ Institute for Marine and Atmospheric Research Utrecht, Utrecht University, Utrecht, the Netherlands \\ ${ }^{2}$ Graduate School of Environmental Studies, Nagoya University, Nagoya, Japan
}

Correspondence to: J. T. M. Lenaerts (j.lenaerts@uu.nl)

Received: 18 December 2013 - Published in The Cryosphere Discuss.: 6 January 2014

Revised: 7 March 2014 - Accepted: 16 March 2014 - Published: 30 April 2014

\begin{abstract}
This paper presents autonomous drifting snow observations performed on the Greenland Ice Sheet in the fall of 2012. High-frequency snow particle counter (SPC) observations at $\sim 1 \mathrm{~m}$ above the surface provided drifting snow number fluxes and size distributions; these were combined with meteorological observations at six levels. We identify two types of drifting snow events: katabatic events are relatively cold and dry, with prevalent winds from the southeast, whereas synoptic events are short lived, warm and wet. Precipitating snow during synoptic events disturbs the drifting snow measurements. Output of the regional atmospheric climate model RACMO2, which includes the drifting snow routine PIEKTUK-B, agrees well with the observed near-surface climate at the site, as well as with the frequency and timing of drifting snow events. Direct comparisons with the SPC observations at $1 \mathrm{~m}$ reveal that the model overestimates the horizontal snow transport at this level, which can be related to an overestimation of saltation and the typical size of drifting snow particles.
\end{abstract}

\section{Introduction}

The Greenland Ice Sheet (GrIS) has been losing mass in the recent two decades (Rignot et al., 2011; Shepherd et al., 2012) with further enhanced mass loss in recent warm years (Hanna et al., 2013). For the period 1992-2008, GrIS mass loss was equally distributed between increased calving from marine-terminating outlet glaciers and a rise in surface melt and subsequent runoff (Van den Broeke et al., 2009). However, large uncertainties remain in the quantification of the individual mass balance components and the temporal variability is large, obscuring an acceleration in the mass balance time series (Wouters et al., 2013). Particularly the surface mass balance (SMB), which is the sum of total mass gain (precipitation) and mass losses (surface sublimation $\left(\mathrm{SU}_{\mathrm{S}}\right)$, drifting snow erosion $\left(\mathrm{SU}_{\mathrm{ds}}\right)$, snow erosion $\left(\mathrm{ER}_{\mathrm{ds}}\right)$ and surface runoff) at the ice sheet surface, is challenging to constrain in the absence of widespread, long-term observations. SMB (usually in units $\mathrm{mm}$ w.e. $\mathrm{yr}^{-1}$ ) is the balance of the processes acting on the ice sheet surface:

$\mathrm{SMB}=\int \mathrm{PR}-\mathrm{SU}_{\mathrm{s}}-\mathrm{SU}_{\mathrm{ds}}-\mathrm{ER}_{\mathrm{ds}}-\mathrm{RUd} t$,

where PR denotes precipitation; $\mathrm{SU}_{\mathrm{s}}$ is surface sublimation; $\mathrm{SU}_{\mathrm{ds}}$ drifting snow sublimation; $\mathrm{ER}_{\mathrm{ds}}$ drifting snow erosion, equivalent to the horizontal divergence of the snow transport $\mathrm{TR}_{\mathrm{ds}}$; and RU surface runoff. Alternatively, regional climate models provide high-resolution gridded and multi-decadal estimates of SMB, and explicitly quantify individual SMB components (Ettema et al., 2009; Fettweis, 2007; Rae et al., 2012; Van Angelen et al., 2013). These models have indicated that the temporal and spatial variability of GrIS SMB is largely driven by precipitation and runoff, with snow sublimation and erosion one order of magnitude smaller (Lenaerts et al., 2012b). However, in the cold ice sheet interior, where katabatic forcing invokes strong and unidirectional winds throughout most of the year (Van Angelen et al., 2011), surface runoff is negligible and drifting snow sublimation and erosion are the only processes that remove mass from the surface. Drifting snow is known to enhance snow sublimation and locally to erode the surface snow layer, leading to a spatial redistribution of snow that is controlled by variations in 


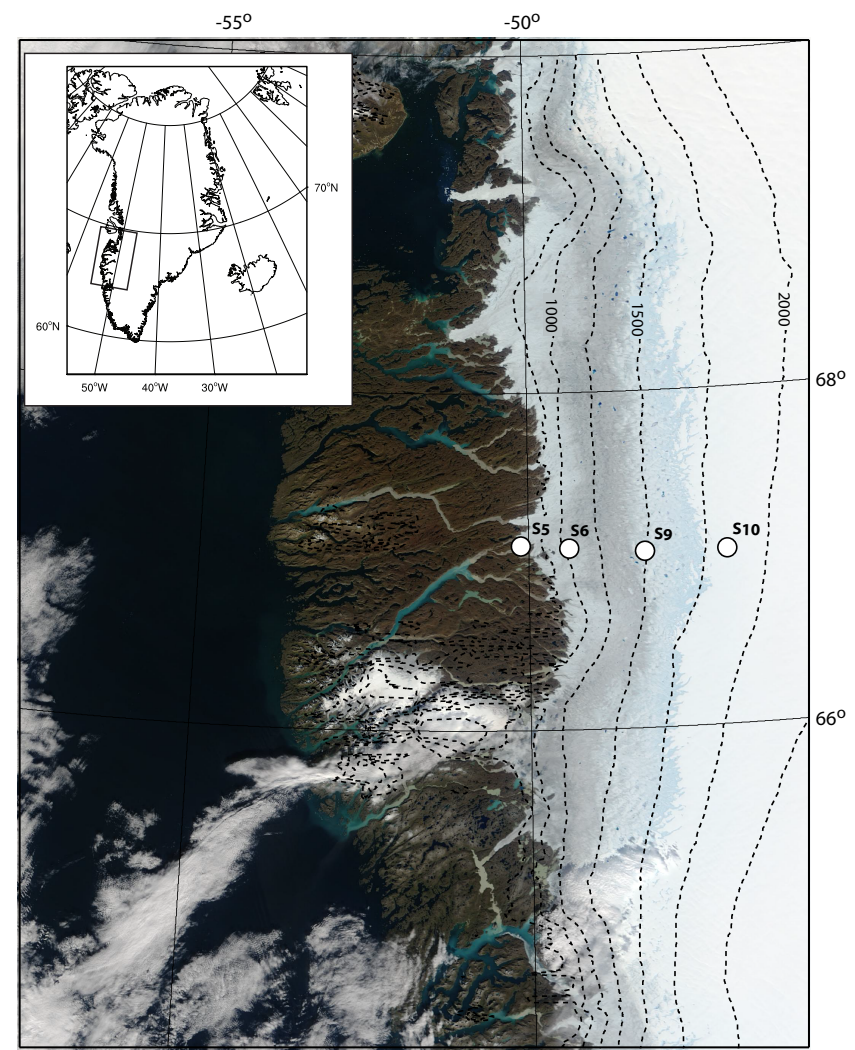

Fig. 1. Map of the location of the K-transect with stations S5, S6, S9 and S10. Background shows MODIS satellite image of August 2006. The inset locates the region on the Greenland Ice Sheet.

the surface wind field. The frequency statistics of drifting snow are reasonably well documented, especially in Antarctica (Budd et al., 1966; Schmidt, 1982; Mann et al., 2000; Nishimura and Nemoto, 2005; Gallée et al., 2013) and for the seasonal snow cover in the Northern Hemisphere (Pomeroy et al., 1993; Déry and Yau, 2001); in general, however, the contribution of drifting snow sublimation and erosion to the SMB remains poorly constrained in absence of reliable observations (Cierco et al., 2007). In recent years, snow particle sensors (SPC), which have the ability to directly measure the horizontal snow transport and particle size spectrum, have been deployed in Antarctica (Nishimura and Nemoto, 2005) and the Alps (Vionnet et al., 2012). In contrast, to date no extensive drifting snow measurements have been performed on the GrIS. Here we present results from autonomous, singlelevel SPC measurements collected in the lower accumulation area of western Greenland during fall 2012. These observations are complemented with high-frequency observations of vertical profiles of temperature, humidity and wind and autonomous imaging from automatic cameras. In this paper, we present the SPC measurements, discuss the feedback between drifting snow and climate, and apply these observations to evaluate the drifting snow characteristics simu-
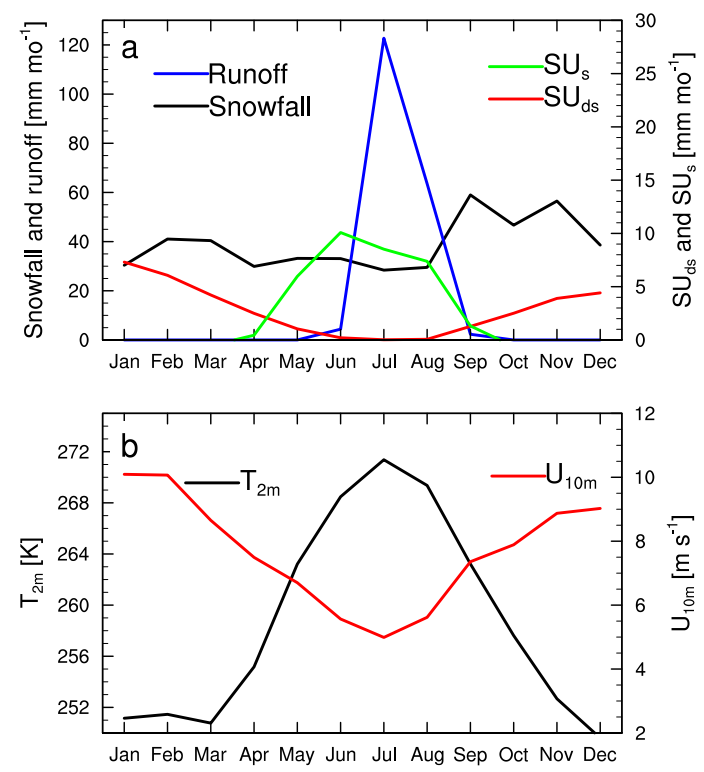

Fig. 2. Seasonal variability of (a) SMB components and (b) $2 \mathrm{~m}$ temperatures and $10 \mathrm{~m}$ wind speed at S10, according to RACMO2 (mean of 1960-2011, Lenaerts et al., 2012b). The left axis in (a) shows snowfall and runoff, the right axis shows drifting snow sublimation $\left(\mathrm{SU}_{\mathrm{ds}}\right)$ and surface sublimation $\left(\mathrm{SU}_{\mathrm{s}}\right)$. All are in mm month ${ }^{-1}$. Note the different scales of left and right axes.

lated by the regional atmospheric climate model RACMO2 (Lenaerts et al., 2012b).

\section{Methods and data}

\subsection{Measurement location}

A representative site for autonomous drifting snow observations should fulfill several criteria: frequent occurrence of drifting snow to quickly obtain a representative sample, low summer melt and modest accumulation rates for stability and to prevent burial of the installed equipment. Low-elevation areas of the GrIS are not suitable, as they are characterised by extensive summer melt, net ablation and limited occurrence of drifting snow (Lenaerts et al., 2012b). Better suited is the lower accumulation zone, where summer ablation and winter accumulation are modest, so that the experiment can be started at the end of the summer.

The site should be easily accessible by helicopter for deployment or recovery work, and have background climate information available. At the western margin of the GrIS, the Institute for Marine and Atmospheric Research of Utrecht University (UU/IMAU) has since 1997 operated automatic weather stations (AWS) on the ice, close to the international airport of Kangerlussuaq (Fig. 1). For the drifting snow setup, we chose the highest station location (S10), located at an elevation of $\sim 1850 \mathrm{~m}$, approximately $300 \mathrm{~m}$ above the equilibrium line (Fig. 1, Van de Wal et al., 2012). The annual 


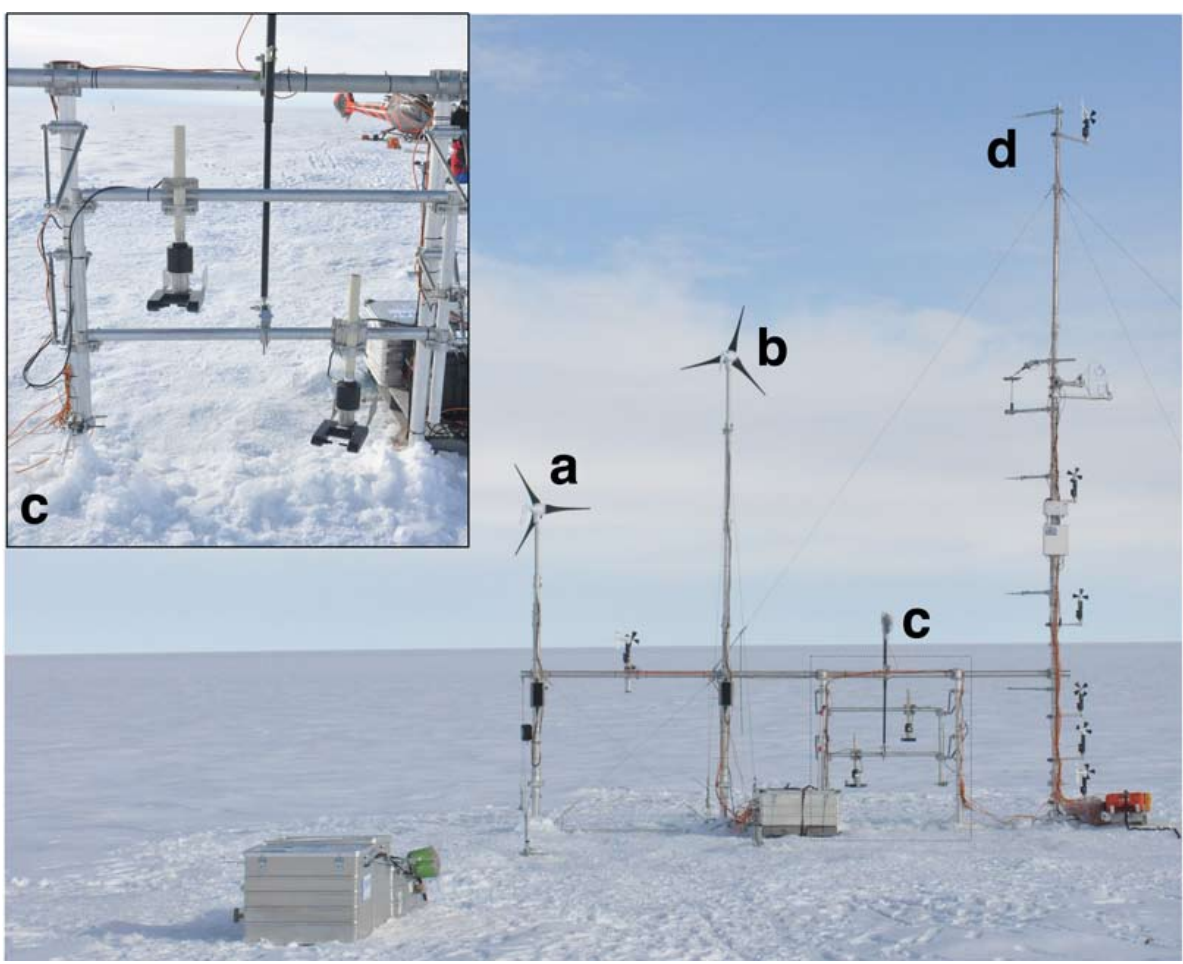

Fig. 3. Drifting snow equipment. Picture taken on 13 August 2012.

average temperature at $\mathrm{S} 10$ is around $-15^{\circ} \mathrm{C}$ (Fig. 2b), and melting occurs only during three months in summer (Fig. 2a). Average $10 \mathrm{~m}$ wind speed is $\sim 8 \mathrm{~m} \mathrm{~s}^{-1}$, with a winter maximum from a combined katabatic and synoptic forcing (Van Angelen et al., 2011) (Fig. 2b). RACMO2 results indicate that the drifting snow season at $\mathrm{S} 10$ extends over nine months, when $\mathrm{SU}_{\mathrm{ds}}$ is larger than both $\mathrm{SU}_{\mathrm{s}}$ and runoff; only June, July and August have few drifting snow events due to melt-related compaction and wetting of the surface snow (Fig. 2a). In winter, $\mathrm{SU}_{\mathrm{ds}}$ is estimated to remove $\sim 10 \%$ of the precipitated snow.

\subsection{Measurements}

The drifting snow measurements (Fig. 3) were performed by snow particle counters (SPC, Sato et al., 1993), manufactured and tested in Japan, and previously used in experiments in the French Alps and Antarctica. The SPC has a self-steering wind vane and is equipped with a super-luminescent diode sensor (Sugiura et al., 2009), which acts as a constant light source during the measurement. When a drifting snow particle passes through the light beam, first the light energy that enters the upwind side decreases, and consequently the same occurs on the downwind side. These signals are converted to two successive electrical pulses, whose voltage is directly proportional to the size of the particle (Sato et al., 1993). Each signal is classified into one of 32 size classes $(\sim 40$ to $500 \mu \mathrm{m})$. This implies that snow particles smaller than $40 \mu \mathrm{m}$ remain undetected. However, we expect that their relative contribution to the snow transport will be limited owing to their small size. Furthermore, the SPC measures the number flux of the snow particles based on each particle's diameter class (Sugiura et al., 2009); hence, the integrated horizontal mass flux $q\left[\mathrm{~kg} \mathrm{~m}^{-2} \mathrm{~s}^{-1}\right]$ of snow can be obtained using

$q=\sum_{c_{\mathrm{d}}=1}^{32} q_{\mathrm{d}}=\sum_{c_{\mathrm{d}}=1}^{32} n_{\mathrm{d}} \frac{4}{3} \pi\left(\frac{d}{2}\right)^{3} \rho_{i}$,

where $q_{\mathrm{d}}$ is the flux per diameter class; $c_{\mathrm{d}}$ represents the index of each of the 32 diameter classes with median diameter $d[\mathrm{~m}] ; n_{\mathrm{d}}$ the measured number flux, expressed here in number of particles per area per time $\left[\mathrm{m}^{-2} \mathrm{~s}^{-1}\right]$; and $\rho_{i}$ the density of ice $\left(=917 \mathrm{~g} \mathrm{~m}^{-3}\right)$. This derivation explicitly assumes that the transported snow particles are fully rounded, a valid approximation in cold and windy regions (Guyomarc'h and Mérindol, 1998).

In our Greenland set-up, the two SPC's were initially installed at $0.5 \mathrm{~m}$ and $1 \mathrm{~m}$ above the snow surface, to capture the vertical gradient of the mass flux. The SPC's were fixed to a horizontal frame that was connected to an electric motor (Fig. 3c), to enable vertical movement of the frame when snow accumulates below the instruments, which was measured by the snow height sensor SR50 (Table 1). The SPC's require much energy $(\sim 15 \mathrm{~W})$, which was provided by two wind generators placed 3 and $4 \mathrm{~m}$ above the surface (Fig. 3a, 
Table 1. A list of all meteorological and turbulence instruments (sensors marked with ${ }^{\mathrm{a}}$ are manufactured by Campbell Scientific, Inc.).

\begin{tabular}{|c|c|c|c|}
\hline Variable & Snow observations & Accuracy & Height (m) \\
\hline Snow transport & SPC, Niigata Electric & unknown & $0.5,1$ \\
\hline Snow height & $\mathrm{SR} 50^{\mathrm{a}}$ & $\pm 0.01 \mathrm{~m}$ & / \\
\hline Variable & Profile observations & Accuracy & \\
\hline$u$ & 05103-L R.M. Young & $\pm 0.3 \mathrm{~ms}^{-1}$ & $0.5,1,1.5,2.5,4,8$ \\
\hline$d d$ & 05103-L R.M. Young & $\pm 3^{\circ} \mathrm{C}$ & $0.5,1,1.5,2.5,4,8$ \\
\hline$T$ & Vaisala HMP155 & $\pm 0.4{ }^{\circ} \mathrm{C}$ at $-20{ }^{\circ} \mathrm{C}$ & $0.5,1,2.5,4,8$ \\
\hline RH & Vaisala HMP155 & $\pm 2 \%(\mathrm{RH}<90 \%)$ & $0.5,1,2.5,4,8$ \\
\hline$T$ & FW3 Type E thermocouple ${ }^{a}$ & $\pm 0.2^{\circ} \mathrm{C}$ & $0.5,1,1.5,2.5,4,8$ \\
\hline Variable & Turbulence observations & Accuracy & \\
\hline$u, v, w$ & CSAT3 Sonic Anemometer ${ }^{a}$ & offset error $< \pm 0.04 \mathrm{~m} \mathrm{~s}^{-1}$ & 5 \\
\hline$T_{\text {sonic }}$ & CSAT3 Sonic Anemometer ${ }^{a}$ & resolution $\pm 0.025^{\circ} \mathrm{C}$ & 5 \\
\hline$T$ & FW3 Type E thermocouple ${ }^{a}$ & $\pm 0.2^{\circ} \mathrm{C}$ & 5 \\
\hline$q$ & LI-COR LI-7500 & RMS noise $<0.005 \mathrm{~g} \mathrm{~kg}^{-1}$ & 5 \\
\hline
\end{tabular}

b). To save energy, the SPC's were switched off at low wind speeds $\left(<5 \mathrm{~ms}^{-1}\right)$, when drifting snow does not occur.

The drifting snow set-up is complemented by an $8 \mathrm{~m}$ high profile tower (Fig. 3d) for measuring atmospheric surface layer profiles at high frequency $(10 \mathrm{~Hz}$, Table 1$)$ for eddy covariance analysis of atmospheric turbulent motions. Wind speed sensors at 6 different heights capture the vertical wind speed profile, and thermocouples measure fast temperature variations. Moreover, at $5 \mathrm{~m}$ height, direct eddy covariance measurements were performed, including a sonic anemometer, a thermocouple and an open path $\mathrm{H}_{2} \mathrm{O} / \mathrm{CO}_{2}$ analyser sampled at $10 \mathrm{~Hz}$ (Table 1). The latter LiCor instrument measures fast humidity fluctuations to quantify the latent heat flux in and above the drifting snow layer. These data from the profile tower will be analysed in a forthcoming paper. We derive observed friction velocity using 5 minute averaged vertical wind speed profiles, a method that yields very similar results and a more continuous data set than the commonly used method to derive friction velocity from a sonic anemometer.

All instruments were installed on 13 August 2012, and checked two weeks after. Unfortunately, the lowest SPC had been malfunctioning since the start of the measurements, and could not be repaired on site. The SPC at $1 \mathrm{~m}$ height worked properly until the first week of October, when strong riming and high wind speeds led to its failure. The meteorological instruments fixed to the mast worked throughout the entire winter, until the equipment was removed in May 2013. This paper focuses on the period during which all instruments were in operation and with significant drifting snow events, that is, 7 September-6 October 2012 (day of year 250-280). Although this implies that we have no data from the core winter, when we expect the strongest drifting events (Lenaerts et al., 2012b), we have detected around 15 drifting snow events in various weather conditions.

Upon data retrieval, we performed a thorough check on the observations and performed corrections or omitted data wherever necessary. Among others, we have corrected wind directions to account for mast tilting and relative humidity is corrected for low temperatures (Reijmer and Oerlemans, 2002). All the measurements are resampled to a half-hourly time resolution.

\subsection{Regional climate model}

The regional atmospheric climate model RACMO version 2.3 (RACMO2 hereafter) combines the high-resolution limited-area model (HIRLAM, Undén et al., 2002) dynamical core and the description of the physical processes of the Integrated Forecast System of the European Centre for Medium Range Forecasts (ECMWF cycle CY33r1, ECMWF-IFS, 2008; van Wessem et al., 2014). It is specifically adapted for use in polar regions, with the inclusion of a snow model that calculates melt of snow and subsequent refreezing and runoff (Bougamont et al., 2005; Ettema et al., 2010), an albedo scheme that follows the temporal evolution of snow grain size (Kuipers Munneke et al., 2011), and, most importantly for this application, drifting snow physics (Lenaerts et al., 2010, 2012a). This drifting snow routine is based on the bulk blowing snow model PIEKTUK-B (Déry and Yau, 1999) and adapted to capture the interactions between drifting snow and the snow surface (based on Guyomarc'h and Mérindol, 1998) and the atmosphere (Lenaerts et al., 2012a). At each model time step ( $2 \mathrm{~min}$ ), near-surface wind speed, temperature, humidity and surface pressure from RACMO2 is passed on to PIEKTUK-B, while PIEKTUK-B gives back $\mathrm{TR}_{\mathrm{ds}}$ and $\mathrm{SU}_{\mathrm{ds}}$ to $\mathrm{RACMO} 2 . \mathrm{ER}_{\mathrm{ds}}$, derived from $\mathrm{TR}_{\mathrm{ds}}$, and $\mathrm{SU}_{\mathrm{ds}}$ are added to the $\mathrm{SMB}$ in the snow scheme, 

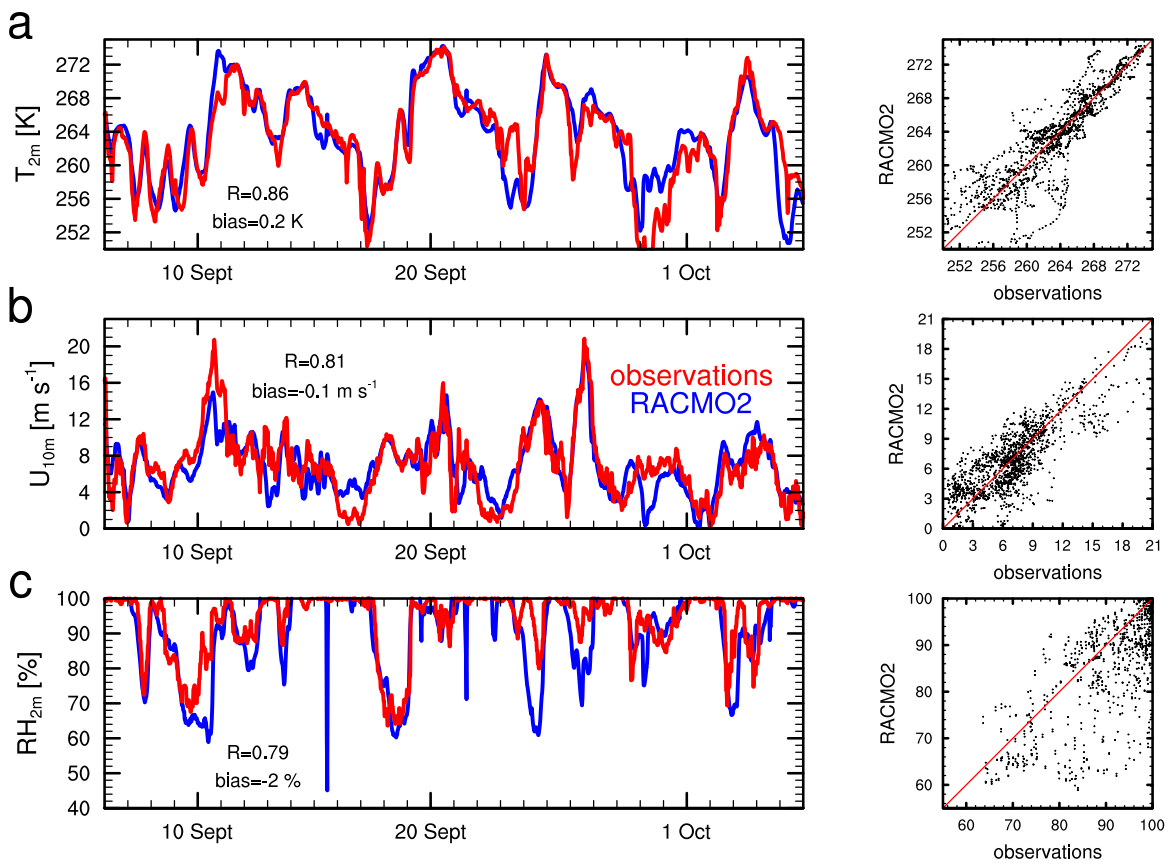

Fig. 4. Time evolution of (a) $2 \mathrm{~m}$ temperature, (b) $10 \mathrm{~m}$ wind speed and (c) relative humidity according to the observations (red lines) and RACMO2 (blue lines). The panels on the right show the correlations between observations and RACMO2, with the $1: 1$ line in red. The correlation coefficient $(R)$ and mean bias are shown in the left panels.

and $\mathrm{SU}_{\mathrm{ds}}$ is translated to the latent heat flux in the surface scheme (see Lenaerts et al., 2012a). Earlier studies have shown good correspondence between observed and simulated drifting snow frequency and transport in Antarctica (Lenaerts et al., 2012a), and near-surface winds in Antarctica (Sanz Rodrigo et al., 2012) and Greenland (Ettema et al., 2010). Here we apply RACMO2 to the Greenland Ice Sheet at a horizontal resolution of $\sim 11 \mathrm{~km}$, forced at its lateral boundaries and sea surface by ERA-Interim reanalysis fields (Dee et al., 2011). The model spatial domain does not only encompass Greenland, but stretches from the Canadian Arctic in the west to Svalbard and Iceland in the east, and from $\sim 55^{\circ} \mathrm{N}$ to $84^{\circ} \mathrm{N}$ from south to north. Furthermore, for this study we use RACMO2's ability to provide high temporal resolution output ( $6 \mathrm{~min}$, resampled to $30 \mathrm{~min})$ to enable a direct comparison with the observations. By default, PIEKTUK-B does not give information on the vertical profiles of snow transport; rather it assumes a certain vertical distribution and directly calculates the vertically integrated transport. To compare single-level measurements of snow transport with simulated snow transport, we retrieved detailed output of a stand-alone PIEKTUK-B model simulation, driven by atmospheric output of RACMO2 (for more details see Lenaerts et al., 2010).

\section{Results}

\subsection{Near-surface climate}

Figure 4 shows observed and simulated half-hourly average $2 \mathrm{~m}$ temperature, $10 \mathrm{~m}$ wind speed and $2 \mathrm{~m}$ relative humidity at $\mathrm{S} 10$. During the measurement campaign, $2 \mathrm{~m}$ temperature (Fig. 4a) varied from $250 \mathrm{~K}$ to the melting point. Cloudfree conditions were present during the first few days, indicated by the strong daily cycle in temperature and relatively low (katabatic) wind speeds (Fig. 4b). Around 10 September, a first synoptic system advected milder air, with temperatures close to the melting point, and high relative humidity and wind speed. Other synoptic disturbances brought similarly mild and windy conditions on 20 September, 26 September and 3 October, while drier conditions with katabatic winds prevailed in between. Figure 4 illustrates that RACMO2 is well able to simulate the temporal variability in temperature, wind speed and relative humidity. The correlation between RACMO2 and observations is significant, with a low mean model bias and a normalised RMSE $<10 \%$ for temperature, $\sim 20 \%$ for wind speed and a larger bias and RMSE for relative humidity, which also exhibits a larger observational uncertainty (Table 1).

The observed snow height change in this period was $\sim 40 \mathrm{~cm}$, which is equivalent to $\sim 120 \mathrm{~mm}$ w.e. of accumulation assuming a typical snow density of $\sim 300 \mathrm{~kg} \mathrm{~m}^{-3}$ (Hawley et al., 2006). The mass gain represents the sum 

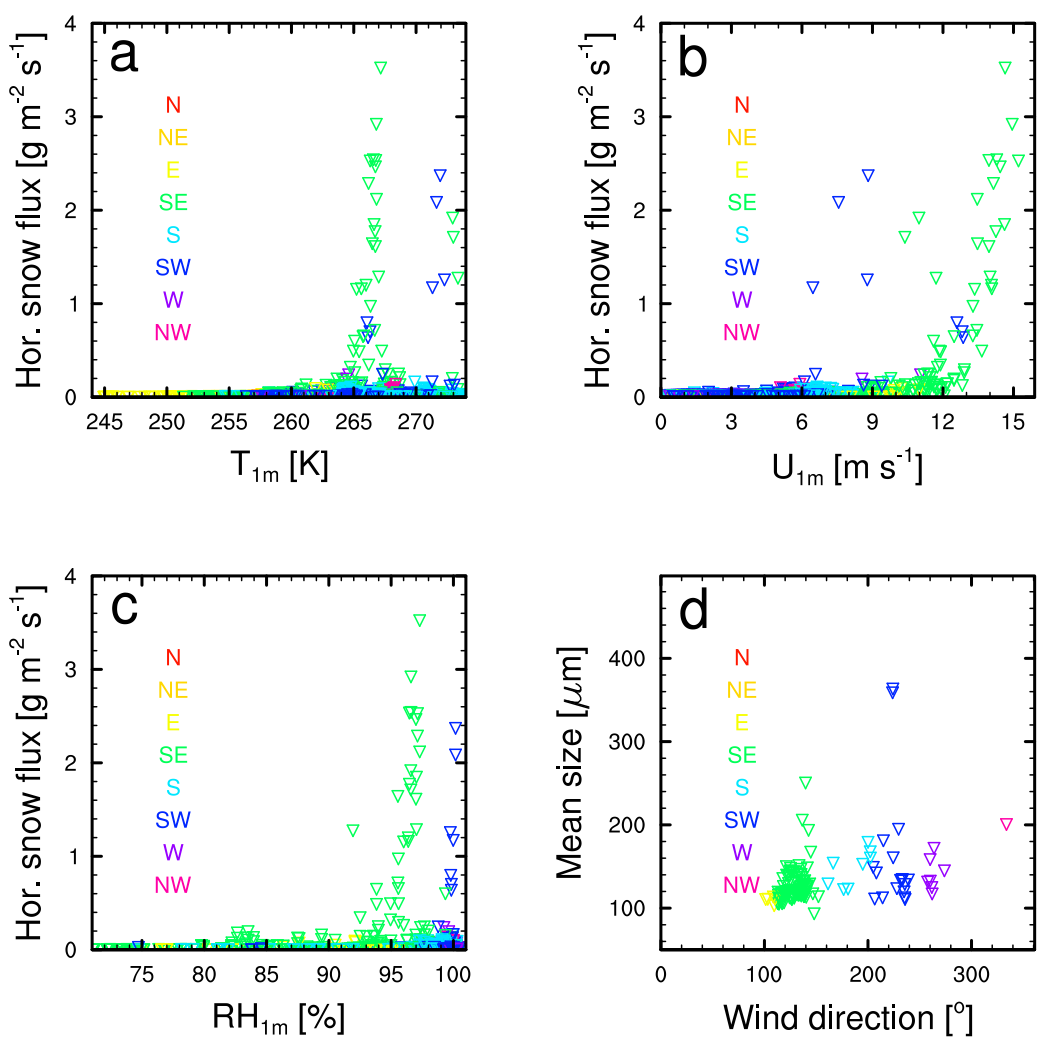

Fig. 5. Horizontal snow flux $\left[\mathrm{g} \mathrm{m}^{-2} \mathrm{~s}^{-1}\right.$ ] vs. (a) temperature (b) wind speed and (c) relative humidity, all measured at $\sim 1 \mathrm{~m}$ above the snow surface. (d) Mean snow particle size as a function of wind direction.

of precipitation and deposition reduced by snow sublimation and erosion. For the same period, RACMO2 simulates $118 \mathrm{~mm}$ w.e. of precipitation, of which $0.5 \mathrm{~mm}$ fell as rain during the passage of a warm low-pressure system on 20 September (Fig. 4a). RACMO2 furthermore simulates a cumulative $\mathrm{SU}_{\mathrm{ds}}$ of $12 \mathrm{~mm}$ w.e., with $\mathrm{ER}_{\mathrm{ds}}$ an order of magnitude smaller $<1 \mathrm{~mm}$ w.e., yielding an SMB of $\sim 106 \mathrm{~mm}$ w.e., which agrees within $\sim 15 \%$ with the measured snow height change under the assumption that the accumulated snow has been compacted under relatively mild and windy conditions (Ligtenberg et al., 2011).

Movies 1 and 2 in the Supplement show the animated hourly camera snapshots during the period analysed here. The weather at S10 is typically characterised by two regimes: dry episodes with mixed synoptic/katabatic winds, mainly directed from the southeast, and intermittent, short-lived passages of low-pressure systems, bringing precipitation and strong southwesterly winds. This climate is clearly reflected in Fig. 5. Drifting snow occurs when the katabatic forcing is strong, with southeasterly winds, relatively low temperatures $(\sim 265 \mathrm{~K})$ and relative humidities $(80-90 \%)$. Drifting snow events forced by synoptic intrusions from the southwest are characterised by higher temperatures $(\sim 270 \mathrm{~K})$ and relative humidities (90-100\%). Figure $5 \mathrm{~b}$ shows that during these events, similar snow transport fluxes are found along with lower wind speeds compared to katabatic events; since these events usually bring snowfall, it is likely that the SPC also measured precipitating snow along with drifting snow, the former having larger particle sizes. This is further demonstrated in Fig. 5d, which shows that the measured mean particle size during drifting snow is typically $100-200 \mu \mathrm{m}$, but rises to $>350 \mu \mathrm{m}$ when winds are from southwest and drifting snow is likely accompanied by snowfall.

In RACMO2, drifting snow occurs when the threshold friction velocity is exceeded (Fig. 6a). The threshold value is a function of surface snow density (Lenaerts et al., 2012a), which in turn is determined by the relative amount of fresh snow in the upper model snow layer. The simulated friction velocity matches the observed friction velocity quite well (Fig. 6a); Figure. 6b shows that timing and frequency of simulated and observed drifting events also qualitatively agree, supporting that the parametrization of the threshold friction velocity in RACMO2, which is based on Antarctic snowdrift frequencies, is universally applicable. For instance, the warm drifting snow event on 20 September led to a small amount of liquid precipitation and melt of the snow surface, increasing surface snow density and the associated threshold friction velocity from 0.4 to $0.55 \mathrm{~m} \mathrm{~s}^{-1}$. As a result, although actual friction velocities remained high during the remainder of the event, drifting snow remained limited 

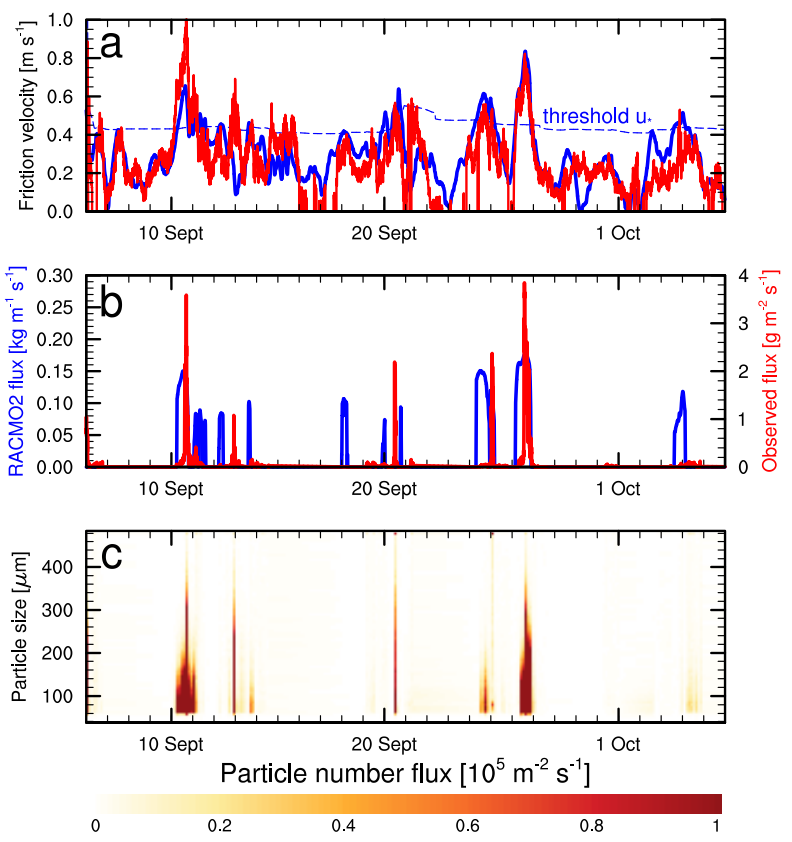

Fig. 6. Time evolution of (a) observed (red) and simulated friction velocity (blue), and threshold friction velocity for drifting snow in RACMO2 (dashed) blue); (b) observed (red) and simulated (blue) drifting snow transport, with the observations originating from 1 level only, whereas RACMO2 snow transport is vertically integrated (mind the different units); and (c) observed number of snow particles per particle size.

to some short episodes, both in the model and in the observations (Fig. 6). Figure $6 \mathrm{c}$ demonstrates that during the strongest events, $>10^{6}$ snow particles of each snow particle class $50-150 \mu \mathrm{m}$ were detected. Generally, these snow particles are very small $(<150 \mu \mathrm{m})$, but the frequency of larger snow particles increases in the largest events, when vertical turbulent motions are sufficiently strong to lift up heavier particles from the surface, which are subsequently entrained in the drifting snow layer.

\section{Case studies}

For a more detailed analysis of the drifting snow characteristics at $\mathrm{S} 10$ and the ability of RACMO2 to simulate these, we focus on two strong events: an event without snowfall that occurred on 24 September 2012, and a mixed snowfall and drifting snow event on 26 September 2012.

\subsection{Dry event: 24 September 2012}

On 24 September 2012, winds at S10 were from the southeast during the entire day (Fig. 7a). During the afternoon a low pressure area moved from south to north across Baffin Bay (Fig. 8), bringing precipitation at S10 and changing the wind direction to southerly in the evening. The automatic
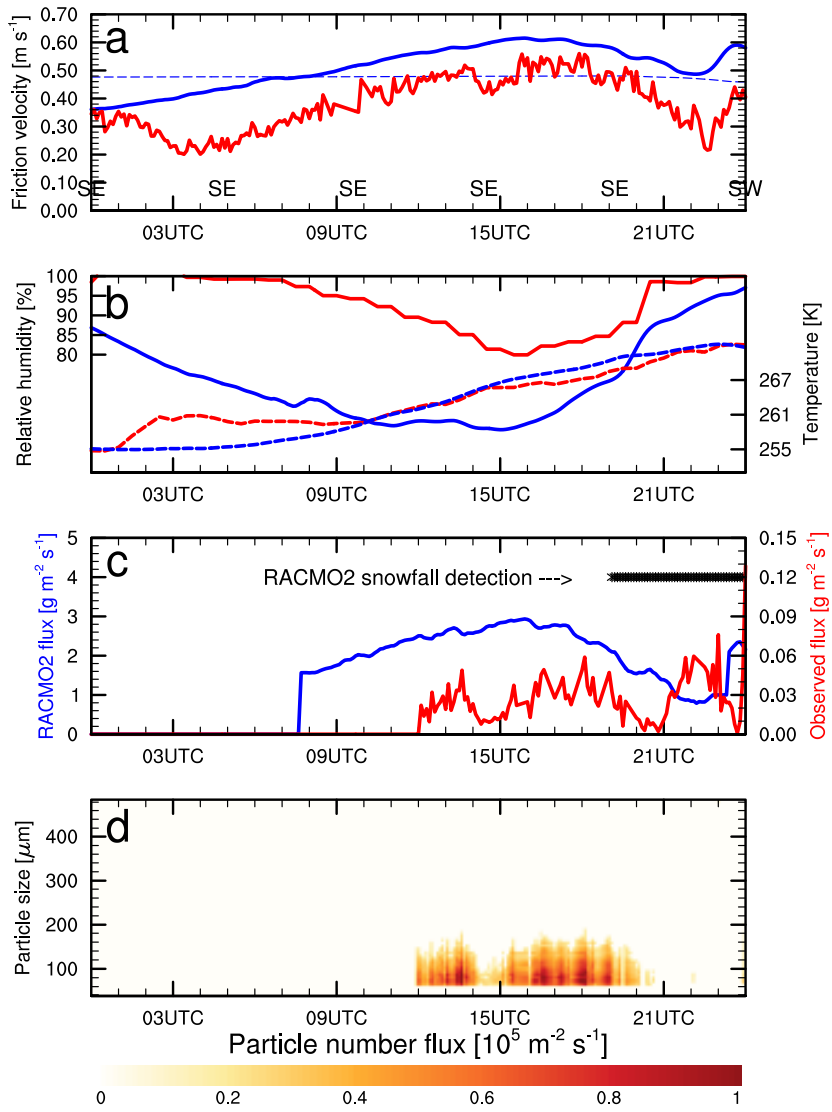

Fig. 7. Time evolution on 24 September 2012 of (a) observed (red) and simulated friction velocity (blue) and wind direction (indicated above bottom axis), and threshold friction velocity for drifting snow in RACMO2 (dashed blue); (b) observed (red) and simulated (blue) relative humidity (solid) and temperature (dashed) at $\sim 1 \mathrm{~m}$ above the surface; (c) observed (red) and simulated (blue) single-level (1 m) drifting snow transport (mind the different scales); and (d) observed number of snow particles per particle size. The crosses in (c) indicate the occurrence of snowfall in RACMO2.

camera (Fig. 9) detected a clear start of the day, with low temperatures of $\sim-18^{\circ} \mathrm{C}$ (Fig. 7b), followed by a gradual rise in near-surface temperature, humidity and wind speed during the afternoon and evening. RACMO2 simulates drifting snow to start at 08:00 UTC (note that local time is UTC-3 h), whereas the observations at $1 \mathrm{~m}$ detected the first drifting snow at 12:00 UTC; this appears to be related to an overestimation of friction velocity in RACMO2 (Fig. 7a). The good visibility in the image of 13:00 UTC and 16:00 UTC indicate that this was a small drifting snow event. However, movement of irregularities at the surface can be discerned between the two snapshots (Fig. 9), indicative of the occurrence of drifting snow. The camera images indicate that the skies were clear until 19:00 UTC, and first snowfall in RACMO2 only started around that time (Fig. 7c). Moreover, the observations do not show an increase of large $(>200 \mu \mathrm{m})$ snow 

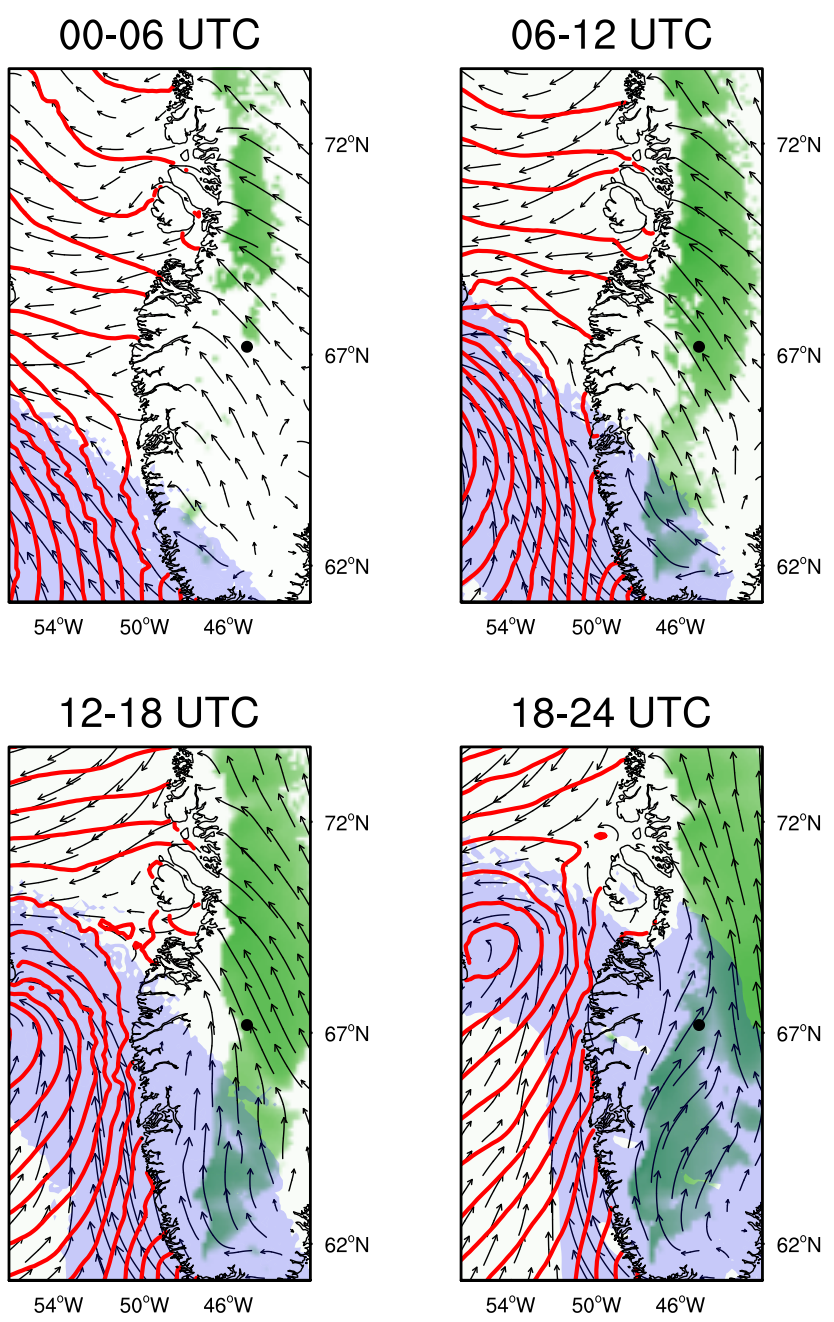

Fig. 8. Time evolution of the large-scale weather situation on 24 September 2012, with sea-level pressure (red lines), $10 \mathrm{~m}$ wind (black arrows), precipitation (shaded blue if $>1 \mathrm{~mm}$ w.e. per $6 \mathrm{~h}$ ) and vertically integrated drifting snow transport (shaded green if $>$ $6000 \mathrm{~kg} \mathrm{~m}^{-1}$ per $6 \mathrm{~h}$ ). The location of $\mathrm{S} 10$ is indicated by the black dot in each panel.

particles, which is indicative of the absence of (many) precipitating snow particles. This implies that most of the drifting snow event was not associated with snowfall.

Particle size distributions in drifting snow models are usually parameterised by a two-parameter gamma distribution (Schmidt, 1982) with a shape parameter $\alpha$ constant with height. In PIEKTUK-B, $\alpha$ is assumed to be equal to 2 , which has been estimated from observations in Antarctica close to the snow surface (Déry and Yau, 1999). Figure 10a shows the observed and simulated particle size distributions. The simulated particle sizes are underestimated by an approximate factor of two, if we use mean particle diameter $(\sim 100 \mu \mathrm{m}$ and $\sim 50 \mu \mathrm{m}$, respectively). This suggests that drifting snow particles are larger in Greenland than those typically ob- served on Antarctica (Nishimura and Nemoto, 2005; Yang and Yau, 2008). When a gamma distribution is fitted to the observed spectra, values of $\alpha$ range from 5 to 8 .

Smaller snow particles are lighter, and therefore more easily suspended in the drifting snow layer. Therefore, larger amounts of drifting snow particles are simulated higher in the drifting snow layer in PIEKTUK-B than in the observations (Fig. 10b), and we find an overestimation of the simulated $\mathrm{TR}_{\mathrm{ds}}$ of several orders of magnitude (Fig. 10c) at all temporal snapshots during the event of 24 September 2012. Accumulated over the day, PIEKTUK-B simulates the local snow horizontal transport at $1 \mathrm{~m}$ to be $\sim 120 \mathrm{~kg} \mathrm{~m}^{-2}$, whereas the SPC measured around $\sim 1.5 \mathrm{~kg} \mathrm{~m}^{-2}$ of cumulative snow transport at that height.

\subsection{Mixed snowfall and drifting snow event: 26 September 2012}

Here we focus on the strongest measured event during the campaign, occurring on 26 September 2012. Figure 11 shows the development of the large-scale synoptic situation during that day. In the early night (00:00-06:00 UTC), we see the strong (katabatic) southeasterly winds at S10. During the second part of the morning (06:00-12:00 UTC) a lowpressure system has developed that started to move northward along the coast, strengthening the katabatic winds with a synoptic component. This low-pressure system moved further northward in the afternoon, leading to a transient wind direction change from east to south at S10 (Fig. 12a). In the evening, the system moved north of S10 and decreased in strength (18:00-00:00 UTC). Our automatic camera made hourly snapshots of the event (Fig. 13), which show clear conditions in the morning with some drifting snow close to the surface (11:00 UTC), heavy drifting snow with low visibility at noon (15:00 UTC), and quieter conditions with overcast skies and high humidity in the afternoon (19:00 UTC).

RACMO2 simulates small drifting snow transport $\left(\mathrm{TR}_{\mathrm{ds}}\right)$ during the earlier morning from 04:00 UTC onwards, increasing in the afternoon and ceasing in the evening (Fig. 11). Figure 12 shows that the SPC at $1 \mathrm{~m}$ started to detect drifting snow at 07:30 UTC. During the remainder of the morning, the drifting snow was probably confined to the saltation layer close to the surface, with marginal values at $1 \mathrm{~m}$, which is confirmed by the webcam image of 11:00 UTC (Fig. 13). At 13:00 UTC, a sudden increase in $\mathrm{TR}_{\mathrm{ds}}$ was observed, concurring with an increase in friction velocity from $0.55 \mathrm{~m} \mathrm{~s}^{-1}$ to $0.8 \mathrm{~m} \mathrm{~s}^{-1}$. Along with an increase in $\mathrm{TR}_{\mathrm{ds}}, \mathrm{RACMO} 2$ simulates the onset of snowfall around this time (Fig. 12c), which likely contributed to the sudden increase in the detection of (mainly larger) snow particles (Fig. 12d). Also during this event, we see that the model overestimates the observed number fluxes and horizontal transport, although the model bias is smaller than in the katabatic case (Fig. 12). The singlelevel snow transport at 26 September is $\sim 330 \mathrm{~kg} \mathrm{~m}^{-2}$, and the SPC measured $\sim 50 \mathrm{~kg} \mathrm{~m}^{-2}$. 

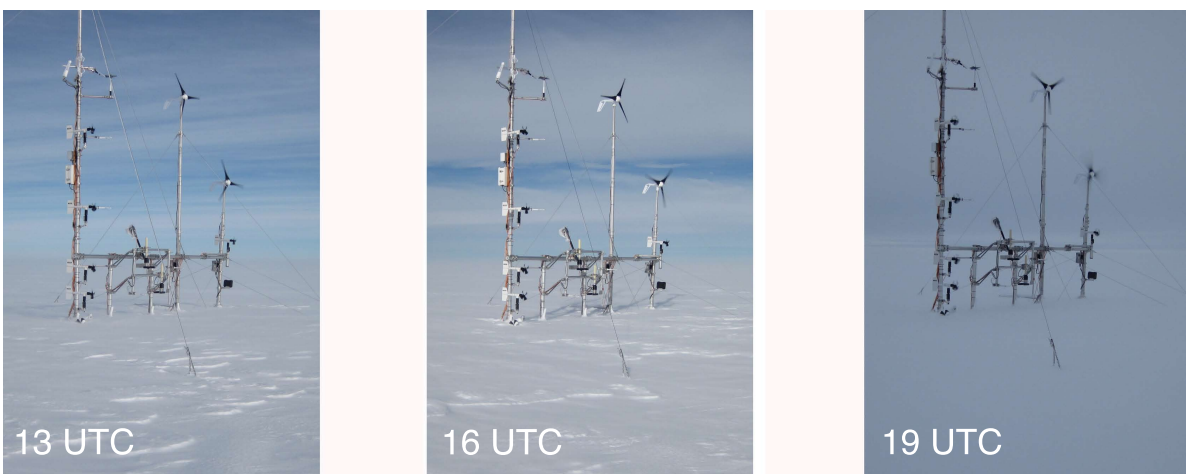

Fig. 9. Automatic camera images of the measurement system on 26 September at 13:00 UTC, 16:00 UTC and 19:00 UTC. The automatic camera was positioned $\sim 10 \mathrm{~m}$ away of the instrumental set-up.

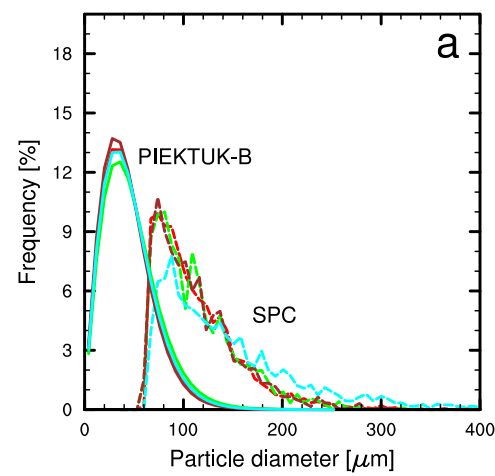

12 UTC

16 UTC

20 UTC

24 UTC
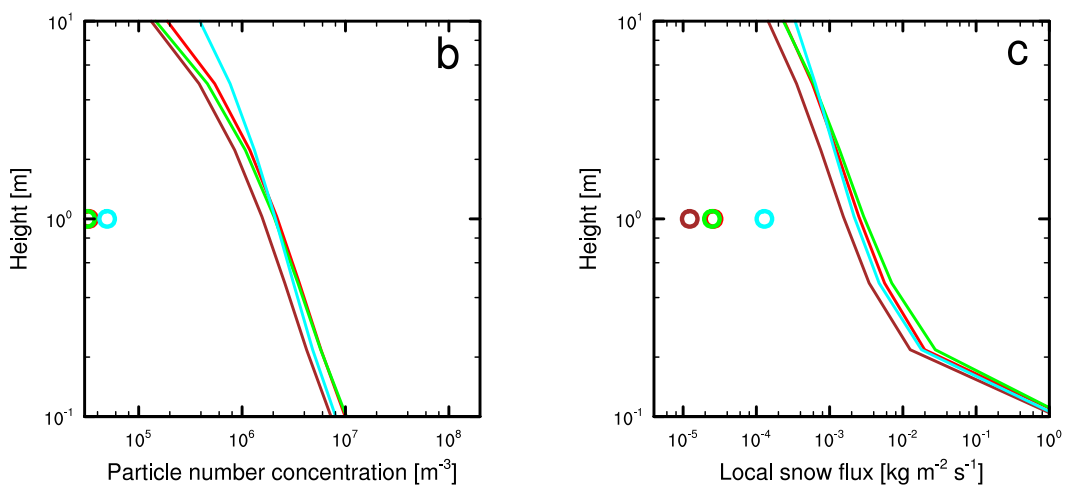

Fig. 10. Snapshots of drifting snow characteristics during 24 September 2012. (a) Relative frequency of drifting snow particle sizes at $1 \mathrm{~m}$ above the surface according to PIEKTUK-B (solid lines) and observations (dotted lines); (b) and (c) vertical profiles of simulated particle concentration and horizontal snow flux (solid lines) and observed particle concentration and horizontal snow flux at $\sim 1 \mathrm{~m}$ height (filled dots).

\subsection{Sensitivity to input parameters}

Drifting snow transport in RACMO2/PIEKTUK-B is significantly overestimated in the katabatic case, but less so during the synoptic event. This can have various reasons: (1) the better agreement between observed and simulated friction velocity in the synoptic case; (2) the synoptic case is associated with fresh snowfall contributing to the observed transport; therefore, the effect of larger (fresh) snow particles may com- pensate for the model flux overestimation; or (3) a more general model deficiency in properly simulating the characteristics of small drifting snow events such as on 24 September, when saltation is the dominant transport process and snow suspension is limited (Bintanja, 2000). Model evaluation in Antarctica and in Wyoming, northwestern USA (Yang and Yau, 2008), showed similarly high simulated particle concentrations in PIEKTUK-B. We also find that the shape parameter $\alpha$ of the gamma snow particle size distribution is much 

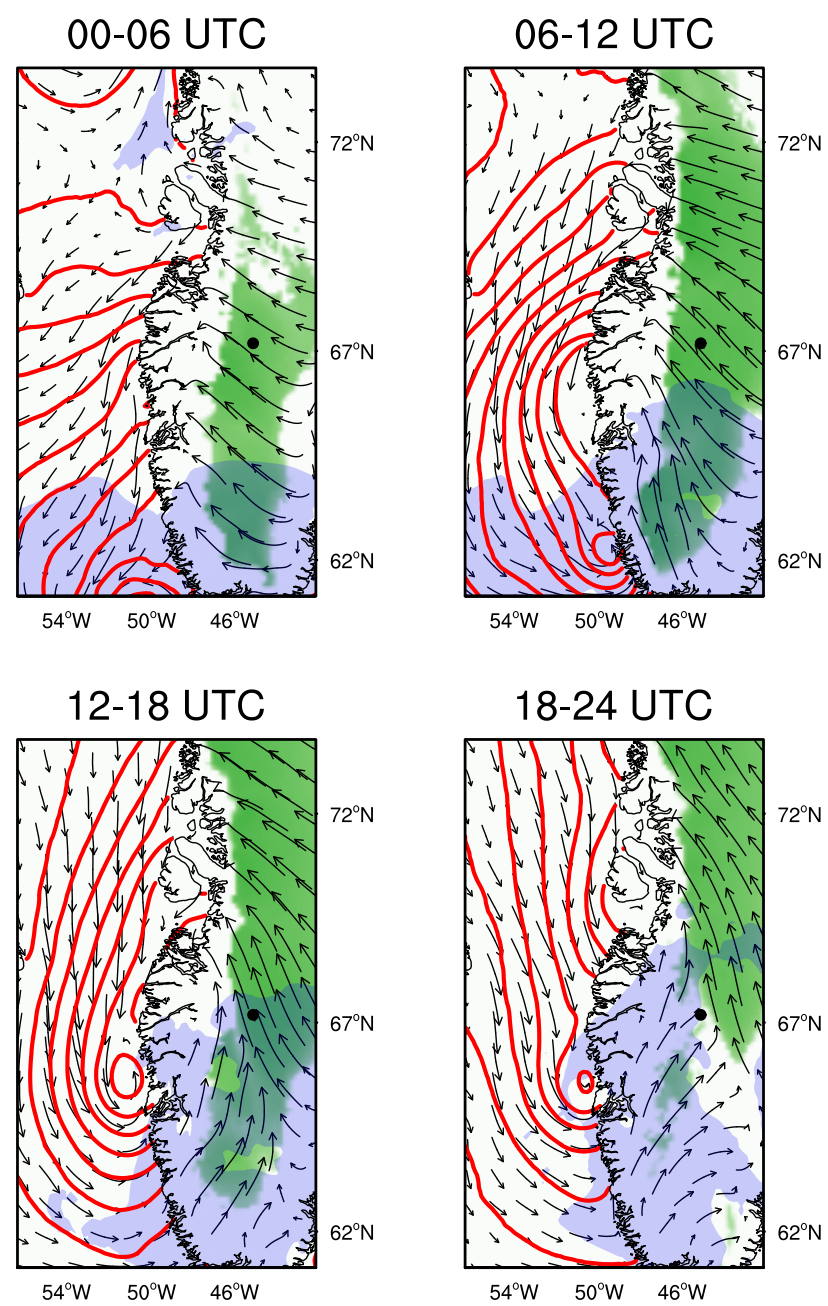

Fig. 11. Time evolution of the large-scale weather situation on 26 September 2012, with sea-level pressure (red lines), $10 \mathrm{~m}$ wind (black arrows), precipitation (shaded blue if $>1 \mathrm{~mm}$ w.e. per $6 \mathrm{~h}$ ) and vertically integrated drifting snow transport (shaded green if $>$ $6000 \mathrm{~kg} \mathrm{~m}^{-1}$ per $6 \mathrm{~h}$ ). The location of $\mathrm{S} 10$ is indicated by the black dot in each panel.

larger (5-8) in the observations than used in PIEKTUK-B, where $\alpha$ is assumed to be equal to 2 and constant with height. This suggests that $\alpha$ should be varying regionally (depending on climate) and vertically. In agreement with the results presented here, the observations pointed to a shape parameter $\alpha$ approaching 5 in Antarctica and close to 7 at $\mathrm{z}=1 \mathrm{~m}$ at the Wyoming site. Yang and Yau (2008) proposed the introduction of a variable $\alpha$ that increases with height in PIEKTUK$\mathrm{B}$, which decreased the model bias of simulated particle concentrations in the upper drifting layer. However, the timeintegrated $\mathrm{TR}_{\mathrm{ds}}$ were not significantly altered by this model improvement.

To test the sensitivity of the simulated snow transport in PIEKTUK-B in the two case studies, we performed several
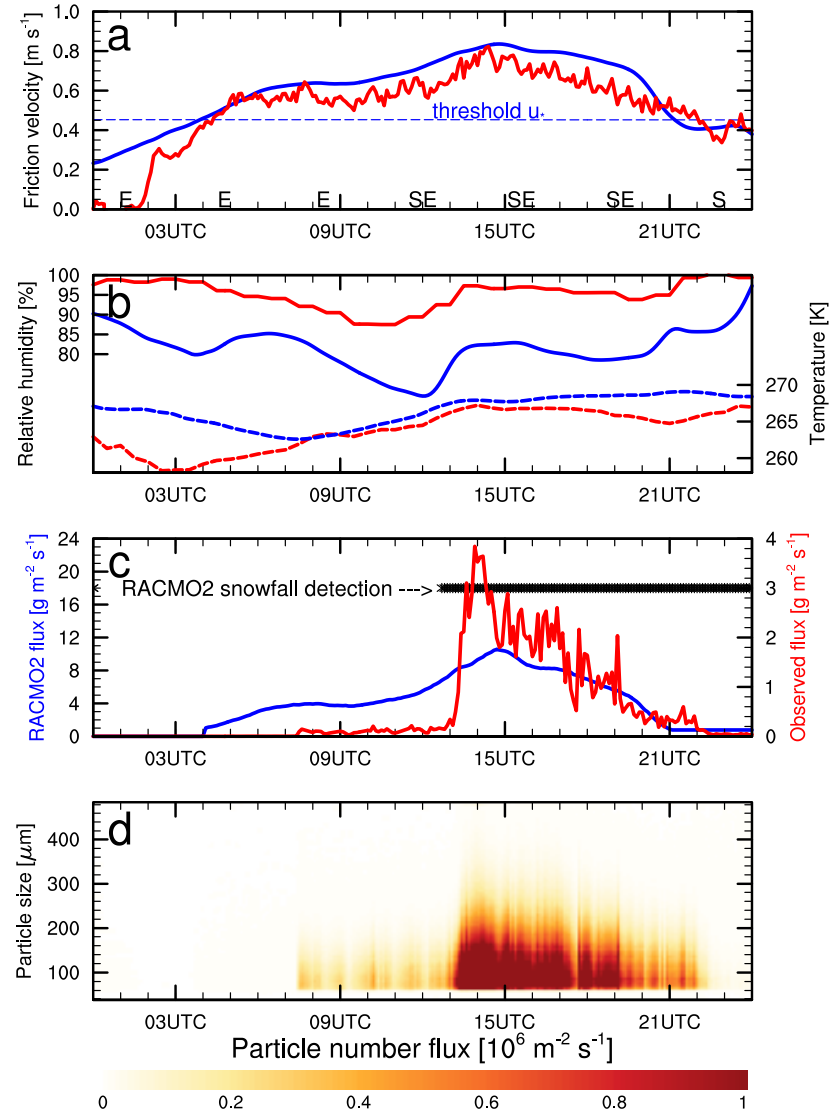

Fig. 12. Time evolution on 26 September 2012 of (a) observed (red) and simulated friction velocity (blue) and wind direction (indicated above bottom axis), and threshold friction velocity for drifting snow in RACMO2 (dashed blue); (b) observed (red) and simulated (blue) relative humidity (solid) and temperature (dashed) at $\sim 1 \mathrm{~m}$ above the surface; (c) observed (red) and simulated (blue) drifting snow transport, with the observations originating from 1 level only, whereas RACMO2 snow transport is vertically integrated (mind the different units); and (d) observed number of snow particles per particle size. The crosses in (c) indicate the occurrence of snowfall in RACMO2. Note that the label bar legend in (d) is increased by a factor of 10 compared to Fig. 6.

additional simulations with changes in the following input parameters:

1. Drifting snow density $(\rho)$ : we test the assumption that the transported snow particles are fully rounded; this can be performed by decreasing the assumed density of transported snow. We change the density $\rho$ to 500 and $700 \mathrm{~kg} \mathrm{~m}^{-3}$.

2. The mean particle radius of snow particles in saltation $\left(r_{\text {salt }}\right)$ : by default, this parameter is set equal to $100 \mu \mathrm{m}$. Increasing $r_{\text {salt }}$ dampens the saltation process close to the surface and the availability of snow particles to get suspended in the atmosphere. We test this by increasing $r_{\text {salt }}$ to 200 and $400 \mu \mathrm{m}$. 

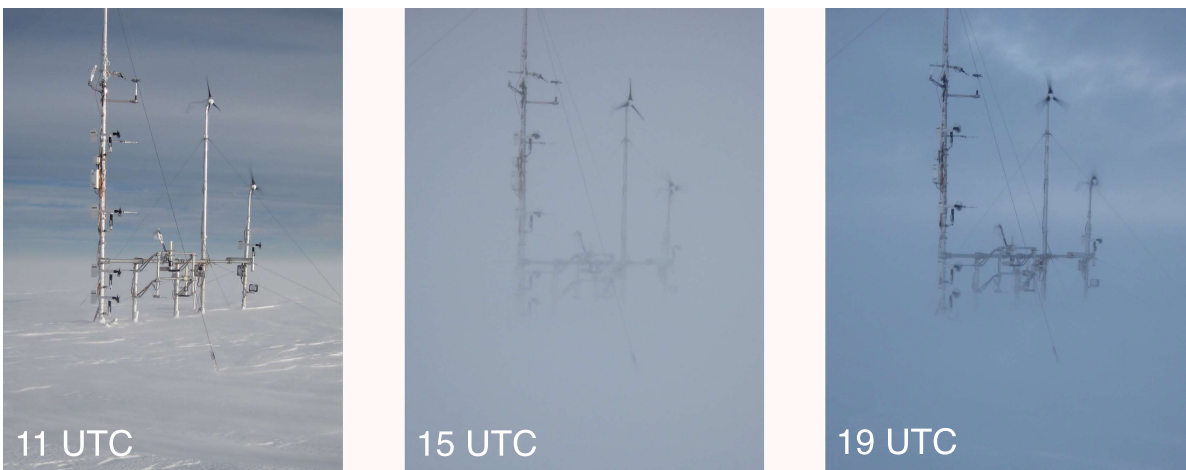

Fig. 13. Automatic camera images of the measurement system on 26 September at 11:00 UTC, 15:00 UTC and 19:00 UTC. The automatic camera was positioned $\sim 10 \mathrm{~m}$ away of the instrumental set-up.

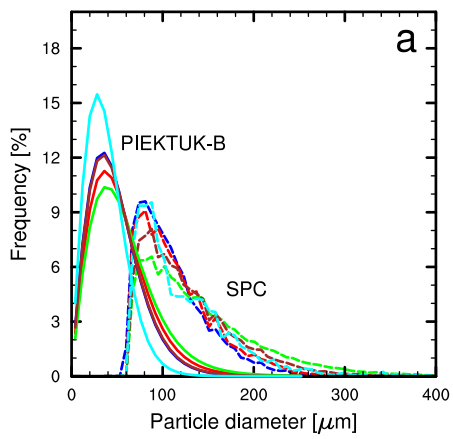

8 UTC

12 UTC

16 UTC

20 UTC

24 UTC
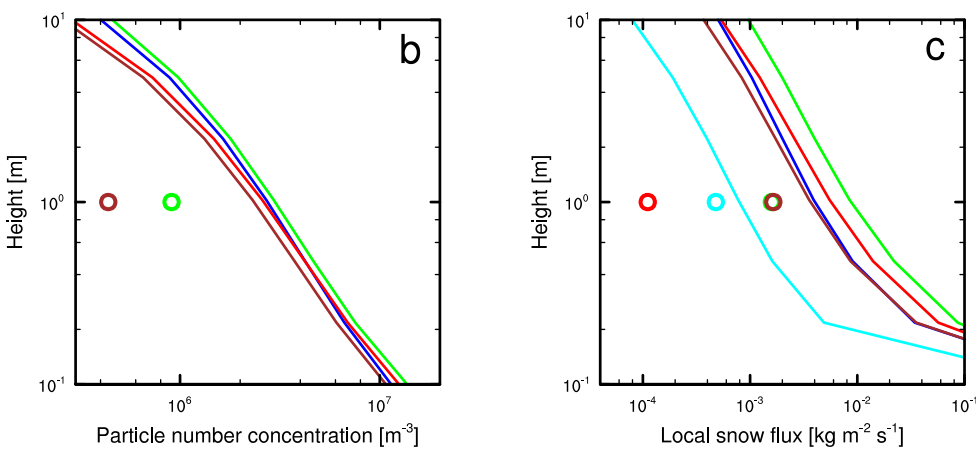

Fig. 14. Snapshots of drifting snow characteristics during 26 September 2012. (a) Relative frequency of drifting snow particle sizes at $1 \mathrm{~m}$ above the surface according to PIEKTUK-B (solid lines) and observations (dotted lines); (b) and (c) vertical profiles of simulated particle concentration and horizontal snow flux (solid lines) and observed particle concentration and horizontal snow flux at $\sim 1 \mathrm{~m}$ height (filled dots).

3. Drifting snow particle distribution shape parameter $(\alpha)$ : as outlined before, the SPC observations suggest a larger shape parameter $\alpha$ than 2 of the snow particle size distribution. We change $\alpha$ to 5 and 8 to test this hypothesis.

4. Friction velocity $\left(\mathrm{u}_{*}\right)$ : the snow transport depends on wind speed in a highly non-linear fashion (e.g. Lenaerts et al., 2012b). Therefore, small biases in the simulated wind speed could strongly affect the strength of snow transport. Figure 6 illustrates that simulated friction velocity $\mathrm{u}_{*}$ agrees with the observed $\mathrm{u}_{*}$, although it seems to underestimate the strongest wind events. Here we account for this potential underestimation and the uncertainty in the observations by perturbing the friction velocity $\mathrm{u}_{*}$ with a constant $\pm 10 \%$.

Table 2 summarises the sensitivity simulations. The drifting snow model is highly sensitive to changes in the input parameters, in particular to (2) and (3), but also to (1) and (4). The resulting local snow transport decreases and increases with several orders of magnitude in response to a doubling of $\mathrm{r}_{\text {salt }}$ and $\alpha$, respectively. The strong dependency upon $\mathrm{r}_{\text {salt }}$ 
Table 2. Overview of simulations that analyse the sensitivity of the drifting snow model to its input parameters. Shown is the daily accumulated snow transport at $1 \mathrm{~m}$ above the surface in $\mathrm{kg} \mathrm{m}^{-2}$ during the two case studies.

\begin{tabular}{lll}
\hline Experiment & $\begin{array}{l}\text { Dry event } \\
(24 \text { September })\end{array}$ & $\begin{array}{l}\text { Precipitation event } \\
(26 \text { September })\end{array}$ \\
\hline SPC & 1.5 & 50 \\
control & 121 & 331 \\
\hline$\rho=500 \mathrm{~kg} \mathrm{~m}^{-3}$ & 448 & 1336 \\
$\rho=700 \mathrm{~kg} \mathrm{~m}^{-3}$ & 221 & 630 \\
\hline$r_{\text {salt }}=200 \mu \mathrm{m}$ & 4.5 & 14 \\
$r_{\text {salt }}=400 \mu \mathrm{m}$ & 0.15 & 0.5 \\
\hline$\alpha=5$ & 2500 & $\sim 10^{4}$ \\
$\alpha=8$ & $2 \times 10^{5}$ & $>10^{6}$ \\
\hline$u_{*}-10 \%$ & 67 & 212 \\
$u_{*}+10 \%$ & 199 & 502 \\
\hline$r_{\text {salt }}=200 \mu \mathrm{m}, \alpha=5$ & 0.45 & 90 \\
\hline
\end{tabular}

indicates that the simulated contribution of saltation to the snow transport at $1 \mathrm{~m}$ is probably overestimated at $\mathrm{S} 10$ due to an underestimation of $r_{\text {salt }}$. The high sensitivity to $\alpha$ is due to the non-linear relation between the particle radius and the snow transport (Eq. 1). If we apply a larger $r_{\text {salt }}(200 \mu \mathrm{m})$ and a $\alpha$ that results from the SPC measurements $(\alpha=5)$, the resulted simulated snow transport at $1 \mathrm{~m}$ agrees with the observations within an order of magnitude in both case studies (Table 2).

\section{Conclusions}

This paper presents the first detailed observations of drifting snow on the GrIS, performed during fall 2012 at site S10, located along the K-transect at $\sim 1850 \mathrm{~m}$ in the accumulation area of the western GrIS. During $\sim 30$ days, a single-level SPC at $1 \mathrm{~m}$ above the snow surface continuously measured snow horizontal transport, complemented by high-frequency vertical profiles of atmospheric variables and hourly automatic camera images. At S10, drifting snow events occur during katabatic wind events, when winds are southeasterly and the near-surface atmosphere is dry and relatively cold. Alternatively, drifting snow events may occur at S10 during the passage of synoptic disturbances along the coast, characterised by southwesterly winds and often associated with precipitation and a warmer near-surface atmosphere.

This data set of drifting snow observations is used to evaluate the regional atmospheric climate model RACMO2, which includes the PIEKTUK-B drifting snow model, in terms of its ability to simulate drifting snow characteristics. The model is well able to simulate the near-surface climate and to capture the majority of the observed drifting snow events. Two case studies of drifting snow events are discussed in more detail. The first event is mainly caused by katabatic winds, and the second event by the passage of a low-pressure system. Although the timing of these events is reasonably well estimated, our results indicate that the size of the drifting snow particles in RACMO2 is underestimated. In contrast to Antarctica, where typical drifting snow particle diameter is $\sim 40 \mu \mathrm{m}$, we find mean particle sizes on the order of $\sim 100 \mu \mathrm{m}$. This is likely related to differences in climate conditions, with the atmosphere over the Antarctic ice sheet being windier and colder, yielding smaller surface snow grains and suppressing snow metamorphism (Scambos et al., 2007; Lyapustin et al., 2009), and the type of precipitation, with a larger contribution of small-grain diamond dust in Antarctica (Noone et al., 1999; Walden et al., 2003; Hou et al., 2007).

As a result, drifting snow transport in RACMO2/PIEKTUK-B is significantly overestimated in the default case. However, we show that the simulated transport is extremely sensitive to the model input, in particular to the choice of snow particle size in saltation and of the shape parameter $\alpha$ of the snow particle distribution.

With only single-level observations, it remains unanswered how well the simulated vertical profiles of snow transport compare to reality; future observational studies of drifting snow in Greenland should therefore ideally include multiple-level SPC measurements, to study the variations of size distributions with height. If performed autonomously, the location of the campaign must be carefully selected; S10 along the K-transect appears to be a good candidate for such an experiment.

Acknowledgements. This work was supported by funding from the ice2sea programme from the European Union 7th Framework Programme, grant number 226375. Ice2sea contribution number 178. We thank the editor, S. Déry and two anonymous reviewers for their constructive comments and valuable time in reviewing this paper.

Edited by: F. Dominé

\section{Supplementary material related to this article is available online at http://www.the-cryosphere.net/8/801/ 2014/tc-8-801-2014-supplement.zip.}

\section{References}

Bintanja, R.: Snowdrift suspension and atmospheric turbulence, Part 1: Theoretical background and model description, Bound.Lay. Meteorol., 95, 343-368, 2000.

Bougamont, M., Bamber, J. L., and Greuell, W.: A surface mass balance model for the Greenland Ice Sheet, J. Geophys. Res., 110, F04018, doi:10.1029/2005JF000348, 2005. 
Budd, W. F., Dingle, W. R. J., and Radok, U.: The Byrd Snowdrift Project: Outline and Basic Results, vol. 9 of Antarctic research series, AGU, 1966.

Cierco, F.-X., Naaim-Bouvet, F., and Bellot, H.: Acoustic sensors for snowdrift measurements: how should they be used for research purposes?, Cold. Reg. Sci. Technol., 49, 74-87, doi:10.1016/j.coldregions.2007.01.002, 2007.

Dee, D. P., Uppala, S. M., Simmons, A. J., Berrisford, P., Poli, P., Kobayashi, S., Andrae, U., Balmaseda, M. A., Balsamo, G., Bauer, P., Bechtold, P., Beljaars, A. C. M., van de Berg, L., Bidlot, J., Bormann, N., Delsol, C., Dragani, R., Fuentes, M., Geer, A. J., Haimberger, L., Healy, S. B., Hersbach, H., Hólm, E. V., Isaksen, L., Kållberg, P., Köhler, M., Matricardi, M., McNally, A. P., Monge-Sanz, B. M., Morcrette, J.-J., Park, B.K., Peubey, C., de Rosnay, P., Tavolato, C., Thépaut, J.-N., and Vitart, F.: The ERA-interim reanalysis: configuration and performance of the data assimilation system, Q. J. Roy. Meteor. Soc., 137, 553-597, doi:10.1002/qj.828, 2011.

Déry, S. J. and Yau, M. K.: A bulk blowing snow model, Bound.Lay. Meteorol., 93, 237-251, 1999.

Déry, S. J. and Yau, M. K.: Simulation of blowing snow in the Canadian Arctic using a double-moment model, Bound.-Lay. Meteorol., 99, 297-316, 2001.

ECMWF-IFS: Part IV: Physical Processes (CY33R1), Tech. Rep., European Centre for Medium-Range Weather Forecasts (ECMWF), Reading, UK, 2008.

Ettema, J., van den Broeke, M. R., Van Meijgaard, E., Van de Berg, W. J., Bamber, J. L., Box, J. E., and Bales, R. C.: Higher surface mass balance of the Greenland ice sheet revealed by highresolution climate modeling, Geophys. Res. Lett., 36, L12501, doi:10.1029/2009GL038110, 2009.

Ettema, J., van den Broeke, M. R., van Meijgaard, E., van de Berg, W. J., Box, J. E., and Steffen, K.: Climate of the Greenland ice sheet using a high-resolution climate model - Part 1: Evaluation, The Cryosphere, 4, 511-527, doi:10.5194/tc-4511-2010, 2010.

Fettweis, X.: Reconstruction of the 1979-2006 Greenland ice sheet surface mass balance using the regional climate model MAR, The Cryosphere, 1, 21-40, doi:10.5194/tc-1-21-2007, 2007.

Gallée, H., Trouvilliez, A., Agosta, C., Genthon, C., Favier, V., and Naaim-Bouvet, F.: Transport of snow by the wind: a comparison between observations in Adélie land, Antarctica, and simulations made with the regional climate model MAR, Bound.-Layer Meteor., 146, 133-147, doi:10.1007/s10546-012-9764-z, 2013.

Guyomarc'h, G. and Mérindol, L.: Validation of a forecasting application of blowing snow periods, Ann. Glaciol., 26, 138-143, 1998.

Hanna, E., Navarro, F. J., Pattyn, F., Domingues, C. M., Fettweis, X., Ivins, E. R., Nicholls, R. J., Ritz, C., Smith, B., Tulaczyk, S., Whitehouse, P. L., and Zwally, H. J.: Icesheet mass balance and climate change, Nature, 498, 51-59, doi:10.1038/nature12238, 2013.

Hawley, R. L., Morris, E. M., Cullen, R., Nixdorf, U., Shepherd, A. P., and Wingham, D. J.: ASIRAS airborne radar resolves internal annual layers in the dry-snow zone of Greenland, Geophys. Res. Lett., 33, L04502, doi:10.1029/2005GL025147, 2006.

Hou, S., Li, Y., Xiao, C., and Ren, J.: Recent accumulation rate at Dome A, Antarctica, Chinese Science Bulletin, 52, 428-431, doi:10.1007/s11434-007-0041-3, 2007.
Kuipers Munneke, P., van den Broeke, M. R., Lenaerts, J. T. M., Flanner, M. G., Gardner, A., and van de Berg, W. J.: A new albedo scheme for use in climate models over the Antarctic ice sheet, J. Geophys. Res., 116, D05114, doi:10.1029/2010JD015113, 2011.

Lenaerts, J. T. M., van den Broeke, M. R., Déry, S. J., KönigLanglo, G., Ettema, J., and Munneke, P. K.: Modelling snowdrift sublimation on an Antarctic ice shelf, The Cryosphere, 4, 179190, doi:10.5194/tc-4-179-2010, 2010.

Lenaerts, J. T. M., van den Broeke, M. R., Déry, S. J., van Meijgaard, E., van de Berg, W. J., Palm, S. P., and Sanz Rodrigo, J.: Regional climate modeling of drifting snow in Antarctica, Part I: Methods and model evaluation, J. Geophys. Res., 117, D05108, doi:10.1029/2011JD016145, 2012a.

Lenaerts, J. T. M., van den Broeke, M. R., van Angelen, J. H., van Meijgaard, E., and Déry, S. J.: Drifting snow climate of the Greenland ice sheet: a study with a regional climate model, The Cryosphere, 6, 891-899, doi:10.5194/tc-6-891-2012, 2012b.

Ligtenberg, S. R. M., Helsen, M. M., and van den Broeke, M. R.: An improved semi-empirical model for the densification of Antarctic firn, The Cryosphere, 5, 809-819, doi:10.5194/tc-5-809-2011, 2011.

Lyapustin, A., Tedesco, M., Wang, Y., Aoki, T., Hori, M., and Kokhanovsky, A.: Retrieval of snow grain size over Greenland from MODIS, Remote Sens. Environ., 113, 1976-1987, doi:10.1016/j.rse.2009.05.008, 2009.

Mann, G. W., Anderson, P. S., and Mobbs, S. D.: Profile measurements of blowing snow at Halley, Antarctica, J. Geophys. Res., 105, 24491-24508, doi:10.1029/2000JD900247, 2000.

Nishimura, K. and Nemoto, M.: Blowing snow at Mizuho station, Antarctica, Philos. T. Roy. Soc. A, 363, 1647-1662, 2005.

Noone, D., Turner, J., and Mulvaney, R.: Atmospheric Signals and Characteristics of Accumulation in Dronning Maud Land, Antarctica, J. Geophys. Res., 104, 19191-19212, doi:10.1029/1999JD900376, 1999.

Pomeroy, J., Gray, D., and Landine, P.: The Prairie Blowing Snow Model: characteristics, validation, operation, J. Hydrol., 144 165-192, doi:10.1016/0022-1694(93)90171-5, 1993.

Rae, J. G. L., Aðalgeirsdóttir, G., Edwards, T. L., Fettweis, X., Gregory, J. M., Hewitt, H. T., Lowe, J. A., LucasPicher, P., Mottram, R. H., Payne, A. J., Ridley, J. K., Shannon, S. R., van de Berg, W. J., van de Wal, R. S. W., and van den Broeke, M. R.: Greenland ice sheet surface mass balance: evaluating simulations and making projections with regional climate models, The Cryosphere, 6, 1275-1294, doi:10.5194/tc-6-1275-2012, 2012.

Reijmer, C. and Oerlemans, J.: Temporal and spatial variability of the surface energy balance in Dronning Maud Land, Antarctica, J. Geophys. Res., 107, 4759-4770, 2002.

Rignot, E., Velicogna, I., van den Broeke, M. R., Monaghan, A., and Lenaerts, J. T. M.: Acceleration of the contribution of Greenland and Antarctic ice sheets to sea level rise, Geophys. Res. Lett., 38, L05503, doi:10.1029/2011GL046583, 2011.

Sanz Rodrigo, J., Buchlin, J.-M., van Beeck, J., Lenaerts, J. T. M., and van den Broeke, M. R.: Evaluation of the Antarctic surface wind climate from ERA reanalyses and RACMO2/ANT simulations based on Automatic Weather Stations, Clim. Dynam., 1-24, doi:10.1007/s00382-012-1396-y, 2012. 
Sato, T., Kimura, T., Ishimaru, T., and Maruyama, T.: Field test of a new snow-particle counter (SPC) system, Ann. Glaciol., 18, 149-154, 1993.

Scambos, T., Haran, T., Fahnestock, M., Painter, T., and Bohlander, J.: MODIS-based Mosaic of Antarctica (MOA) data sets: continent-wide surface morphology and snow grain size, Remote Sens. Environ., 111, 242-257, doi:10.1016/j.rse.2006.12.020, 2007.

Schmidt, R.: Vertical profiles of wind speed, snow concentration and humidity in blowing snow, Bound.-Layer Meteor., 223-246, 1982.

Shepherd, A., Ivins, E. R., A, G., Barletta, V. R., Bentley, M. J., Bettadpur, S., Briggs, K. H., Bromwich, D. H., Forsberg, R., Galin, N., Horwath, M., Jacobs, S., Joughin, I., King, M. A., Lenaerts, J. T. M., Li, J., Ligtenberg, S. R. M., Luckman, A., Luthcke, S. B., McMillan, M., Meister, R., Milne, G., Mouginot, J., Muir, A., Nicolas, J. P., Paden, J., Payne, A. J., Pritchard, H., Rignot, E., Rott, H., Sörensen, L. S., Scambos, T. A., Scheuchl, B., Schrama, E. J. O., Smith, B., Sundal, A. V., van Angelen, J. H., van de Berg, W. J., van den Broeke, M. R., Vaughan, D. G., Velicogna, I., Wahr, J., Whitehouse, P. L., Wingham, D. J., Yi, D., Young, D., and Zwally, H. J.: A reconciled estimate of ice-sheet mass balance, Science, 338, 1183-1189, doi:10.1126/science.1228102, 2012.

Sugiura, K., Ohata, T., Yang, D., Sato, T., and Sato, A.: Application of a snow particle counter to solid precipitation measurements under Arctic conditions, Cold. Reg. Sci. Technol., 58, 77-83, doi:10.1016/j.coldregions.2009.03.010, 2009.

Undén, P., Rontu, L., Järvinen, H., Lynch, P., Calvo, J., Cats, G., Cuxart, J., Eerola, K., Fortelius, C., Garcia-Moya, J., Jones, C., Lenderlink, G., McDonald, A., McGrath, R., Navascues, B., Nielsen, N. W., Ødegaard, V., Rodriguez, E., Rummukainen, M., Rööm, R., Sattler, K., Sass, B. H., Savijärvi, H., Schreur, B. W., Sigg, R., The, H., and Tijm, A.: HIRLAM-5 Scientific Documentation, Tech. Rep., Swed. Meteorol., and Hydrol. Inst., Norrköping, Sweden, 2002.

Van Angelen, J. H., van den Broeke, M. R., and van de Berg, W. J.: Momentum budget of the atmospheric boundary layer over the Greenland ice sheet and its surrounding seas, J. Geophys. Res.Atmos., 116, D10101, doi:10.1029/2010JD015485, 2011.
Van Angelen, J. H., Broeke, M. R., Wouters, B., and Lenaerts, J. T. M.: Contemporary (1960-2012) Evolution of the Climate and Surface Mass Balance of the Greenland Ice Sheet, Surv. Geophys., 1-20, doi:10.1007/s10712-013-9261-z, 2013.

Van de Wal, R. S. W., Boot, W., Smeets, C. J. P. P., Snellen, H., van den Broeke, M. R., and Oerlemans, J.: Twenty-one years of mass balance observations along the K-transect, West Greenland, Earth Syst. Sci. Data, 4, 31-35, doi:10.5194/essd-4-312012, 2012.

Van den Broeke, M. R., Bamber, J. L., Ettema, J., Rignot, E., Schrama, E., van de Berg, W. J., van Meijgaard, E., Velicogna, I., and Wouters, B.: Partitioning recent Greenland mass loss, Science, 326, 984-986, doi:10.1126/science.1178176, 2009.

Van Wessem, J. M., Reijmer, C. H., M. Lenaerts, J. T., van de Berg, W. J., van den Broeke, M. R., and van Meijgaard, E.: Updated cloud physics in a regional atmospheric climate model improves the modelled surface energy balance of Antarctica, The Cryosphere, 8, 125-135, doi:10.5194/tc-8-125-2014, 2014.

Vionnet, V., Guyomarch, G., Naaim-Bouvet, F., Martin, E., Durand, Y., Bellot, H., Bel, C., and Pugliese, P.: Occurrence of blowing snow events at an alpine site over a 10-year period: observations and modelling, Adv. Water Resour., 55, 53-63, doi:10.1016/j.advwatres.2012.05.004, 2012.

Walden, V. P., Warren, S. G., and Tuttle, E.: Atmospheric ice crystals over the Antarctic Plateau in winter, J. Appl. Meteorol., 42, 1391-1405, doi:10.1175/15200450(2003)042<:AICOTA>2.0.CO;2, 2003.

Wouters, B., Bamber, J. L., van den Broeke, M. R., Lenaerts, J. T. M., and Sasgen, I.: Limits in detecting acceleration of ice sheet mass loss due to climate variability, Nat. Geosci., 6, 613-616, doi:10.1038/ngeo1874, 2013.

Yang, J. and Yau, M.: A new triple-moment blowing snow model, Bound.-Lay. Meteorol., 126, 137-155, doi:10.1007/s10546-0079215-4, 2008. 